\title{
Effects of different agricultural systems on soil quality in Northern Limón province, Costa Rica
}

\author{
Emma Cornwell \\ Departments of Biology and Environmental Studies, St. Olaf College, 1500 St. Olaf Ave, Northfield, MN 55057 USA; \\ cornwellemma@gmail.com
}

\author{
Received 20-III-2014. C Corrected 20-IV-2014. Accepted 26-V-2014.
}

\begin{abstract}
Conversion of native rainforest ecosystems in Limón Province of Costa Rica to banana and pineapple monoculture has led to reductions in biodiversity and soil quality. Agroforestry management of cacao (Theobroma cacao) is an alternative system that may maintain the agricultural livelihood of the region while more closely mimicking native ecosystems. This study compared physical, biological and chemical soil quality indicators of a cacao plantation under organic agroforestry management with banana, pineapple, and pasture systems; a native forest nearby served as a control. For bulk density and earthworm analysis, 18 samples were collected between March and April 2012 from each ecosystem paired with 18 samples from the cacao. Cacao had a lower bulk density than banana and pineapple monocultures, but greater than the forest $(\mathrm{p}<0.05)$. Cacao also hosted a greater number and mass of earthworms than banana and pineapple $(\mathrm{p}<0.05)$, but similar to forest and pasture. For soil chemical characteristics, three composite samples were collected in March 2012 from each agroecosystem paired with three samples from the cacao plantation. Forest and pineapple ecosystems had the lowest $\mathrm{pH}$, cation exchange capacity, and exchangeable nutrient cations, while cacao had the greatest $(\mathrm{p}<0.05)$. Total nutrient levels of $\mathrm{P}$ and $\mathrm{N}$ were slightly greater in banana, pineapple and pasture than in cacao; probably related to addition of chemical fertilizer and manure from cattle grazing. Forest and cacao also had greater $\% \mathrm{C}$, than other ecosystems, which is directly related to soil organic matter content $(p<0.0001)$. Overall, cacao had more favorable physical, biological and chemical soil characteristics than banana and pineapple monocultures, while trends were less conclusive compared to the pastureland. While organic cacao was inferior to native forest in some soil characteristics such as bulk density and organic carbon, its soil quality did best mimic that of the native forest. This supports the organic cultivation of cacao as a desirable alternative to banana and pineapple monoculture. Rev. Biol. Trop. 62 (3): 887-897. Epub 2014 September 01.
\end{abstract}

Key words: agroforestry, banana (Musa acuminata), cacao (Theobroma cacao), Costa Rica, organic, pineapple (Ananus comosus), pasture, soil quality.

In the Caribbean coastal plain of Costa Rica, conversion of native rainforest ecosystems to monocrop agriculture production has led to habitat loss and biodiversity reductions (Vaughan, Ramírez, Herrera, \& Guries, 2007). Agroforestry systems, consisting of shade trees integrated among primary crops, can more closely mimic the floral and faunal biodiversity of native forests. Past research has shown that after many years of agroforestry management, fields can attain levels of soil quality equal to those of an adjacent native forest system (Isaac,
Gordon, Thevathasan, Oppong, \& QuashieSam, 2005).

One crop that is commonly grown under agroforestry management is cacao (Theobroma cacao). Previous studies indicated that, in comparison to monocrop systems, cacao cultivation has larger nutrient inputs, reduced nutrient losses, and better soil physical properties such as penetrability and bulk density (Young, 1989; Isaac et al., 2005; McNeely \& Schroth, 2006; Vallejo, Roldan, \& Dick, 2010; Tully \& Lawrence, 2011). 
Soil health is very important to successful agriculture. A high quality soil provides an environment for optimum root growth that enhances crop health and productivity (Baldwin, 2006). Beyond merely enhancing the growth of one desired crop, a balanced, healthy soil can sustain the productivity of other animals and plants, support human health, and improve the quality of air and water (Doran, Sarrantonio, \& Liebig, 1996; Bonanomi et al., 2011). Because healthy soil can benefit whole ecosystems, analyzing the soil quality of a certain system of agriculture can provide a strong case for or against its environmental sustainability.

Soil quality is a complex entity that cannot be measured directly. Instead, physical, chemical and biological indicators must be considered. Physical factors such as bulk density give an indication of the quality of soil for adequate root growth and movement of water and air (USDA, 1999). In addition, macroinvertebrate and microbial communities are essential factors to consider in the maintenance of soil fertility, because they play crucial roles in influencing physical and chemical properties of the soil (Sánchez-de Leon, de Melo, Soto, JohnsonMaynard, \& Lugo-Perez, 2006). It is also very important, especially in tropical ecosystems, to maintain high levels of soil organic matter, because this is the primary source of energy, nitrogen and soil structure for soil and plant ecosystems (Sánchez-de Leon et al., 2006). Compared to monocrop systems, agroforestry has been shown to have more abundant and diverse microfauna, and greater levels of soil organic matter (Sánchez-de Leon et al., 2006).

One can also note differences in the soil quality of farms under organic vs. conventional management. The use of chemical fertilizers and pesticides on "conventionally" managed farms can lead to polluted runoff that has detrimental effects on the organisms in the wider ecosystem (Castillo et al., 2006). These chemicals can also affect soil health.

The purpose of this study was to compare physical, biological, and chemical indicators of soil quality on an organic cacao farm under agroforestry management with conventional banana and pineapple monocultures, as well as a neighboring pasture and fragment of primary rainforest. I also compared the soil quality of organic and non-organic cacao cultivation. By adding to the body of research surrounding this topic, I aimed to strengthen the case for cacao agroforestry as an alternative agriculture method that can mitigate the negative effects of deforestation while still providing a livelihood for area farmers.

\section{MATERIALS AND METHODS}

Study area: The study area is located in Pueblo Nuevo de Villa Franca de Guácimo, in Limón Province, Costa Rica $\left(10^{\circ} 20^{\prime} \mathrm{N}-83^{\circ} 20^{\prime}\right.$ $\mathrm{W})$. This area receives a mean annual rainfall of $6000 \mathrm{~mm}$ with a mean air temperature of $26^{\circ} \mathrm{C}$ and is located $40 \mathrm{~m}$ above sea level, in the Premontane Wet Forest Life Zone (Holdridge, 1964; Vaughan et al., 2007). Major soil types (sub-group/great group/suborder/order) on this farm and surrounding areas include typic tropoquept, aeric tropoquept, aquic eutropept, aquic dystrandept, and oxic dystrandept (Obando, 1982).

The primary study site is a 110 ha cacao plantation that has been under organic management since 2002 . This land was originally primary rainforest, but was managed as livestock pasture for many years before its conversion to cacao agriculture in the 1980 s. The primary tree crop, Theobroma cacao, is maintained under shade trees Eucalyptus deglupta, Cocos nucifera, Leucaena leucocephala, and Musa acuminata (R. Wieme, unpublished). Organic fertilizer made of composted coffee husks is applied biannually, and since 2011 an organic herbicide has been applied for weed control; no chemical fertilizers or pesticides have been used in the prior 13yrs. A subterranean system of drainage tubes was installed in 1997 to help maintain adequate soil moisture content (G. Herrera, pers. comm., wesgeova@yahoo.com). There is a strip of cacao farmland bordering the adjacent banana plantation on which the cacao is officially classified as conventional. 
A large banana (Musa acaminata) monoculture borders the cacao plantation on the west and is maintained with regular applications of chemical fertilizers, insecticides, and fungicides. Pasture for cattle grazing borders the north side of the cacao plantation. These pastures consist mainly of African star grass (Cynodon nlemfuensis) with some large isolated trees like Coussapoa villosa, Ocotea sinuata, Erythrina poeppigiana and Hura crepitans and are not chemically treated (Vaughan et al., 2007). A fragment of native primary forest is located approximately $2 \mathrm{~km}$ northeast of the cacao plantation. I also studied a pineapple monoculture that is maintained conventionally with chemical fertilizers, insecticides, fungicides and an intensive system of open drainage ditches. This pineapple monoculture existed on very similar soil types as those of the cacao plantation.

Selection of sampling sites: I selected sampling sites on similar soil types located on roughly the same topographical features, according to an available soil types map (Obando, 1982). To compare banana and pasture with cacao, I selected six paired plots along the cacao plantation with each plot located approximately $15 \mathrm{~m}$ perpendicular to the border between cultivation types.

I also designated six study sites in the pineapple plantation and three control sites in the natural primary forest. For analysis, these sites were paired with six cacao sites to minimize variation due to sampling time; samples for bulk density and earthworm abundance from paired sites were collected on the same day.

On-site analysis of bulk density: At each sampling site described above, I extracted three core samples of known volume to approximately $10 \mathrm{~cm}$ depth at each sampling site; I weighed these samples to determine their fresh weight. A subsample of each soil core was weighed, dried in a microwave oven until mass no longer decreased, and then weighed again to determine dry weight. To calculate the oven-dried weight of the full sample, I used the formula $\mathrm{W}_{\mathrm{d}}=\left(\mathrm{W}_{\mathrm{f}}\right.$ $\left.\mathrm{x} \quad \mathrm{W}_{\mathrm{dsub}}\right) / \mathrm{W}_{\text {fsub }}$, where $\mathrm{W}_{\mathrm{d}}=$ oven dried weight of full sample, $\mathrm{W}_{\mathrm{f}}=$ fresh weight of full sample, and $\mathrm{W}_{\text {dsub }}$ and $\mathrm{W}_{\text {fsub }}$ are the dry and fresh weights of the subsample. I then calculated bulk density using the formula $\left(\mathrm{W}_{\mathrm{d}} / \mathrm{V}\right)$, where $\mathrm{V}=$ soil core volume.

On-site analysis of earthworm abundance: Using a $25 \mathrm{x} 25 \mathrm{~cm}$ quadrant frame, I excavated the soil at each paired sampling site to a depth of $20 \mathrm{~cm}$ and searched by hand for earthworms (Gregory, Shea, \& Bakko, 2005; Sánchez-de Leon et al., 2006). I obtained three replicates at each sampling site and determined the total number and mass of earthworms. Because earthworm abundance varied greatly depending on weather, earthworms from paired sites were collected on the same day; all samples were collected between March 8 and April 19, 2012.

Laboratory analysis of soil samples: For chemical laboratory analysis, I took samples at three of the six paired sampling sites for each agricultural ecosystem on March 27, 2012. At each site, I combined five cores, $10 \mathrm{~cm}$ deep by $4 \mathrm{~cm}$ wide. Samples were sent to the Centro de Investigaciones Agronómicas at the University of Costa Rica, San Pedro de Montes de Oca for laboratory analysis. Chemical laboratory analysis included $\mathrm{pH}$, acidity, cation exchange capacity, concentrations of macro- and micronutrients, $\% \mathrm{C}$ and $\% \mathrm{~N}$.

I used Statgraphics Centurion XVI software (Statpoint Technologies, Inc., 2012) to analyze each soil quality indicator separately for significant differences between crop types. For analysis of the forest ecosystem, I used one-way ANOVA tests. The other ecosystems were compared to their corresponding paired sites in the cacao using paired comparisons two-way parametric ANOVA tests, in order to account for some of the inherent microscale variation in soil characteristics. All ANOVAs were performed after testing for normality and homogeneity of variance (Sokal \& Rohlf, 2012). Unplanned comparisons of means were 
estimated with least significant, Tukey or Scheffe confidence intervals.

\section{RESULTS}

Bulk density: Among all ecosystems, mean soil bulk density was greatest in pineapple $\left(\bar{x}=0.79 \mathrm{~g} / \mathrm{cm}^{3}\right)$ and lowest in forest $\left(\bar{x}=0.48 \mathrm{~g} / \mathrm{cm}^{3}\right)(\mathrm{F}=13.1 ; \mathrm{df}=7,127 ; \mathrm{p} \leq 0.0001$, Fig. 1). Forest soil bulk density was less than any other crop, including its paired cacao site $\left(0.66 \mathrm{~g} / \mathrm{cm}^{3}\right) \quad(\mathrm{p}<0.05$, Fig. 1). Banana $(\bar{x}$ $\left.=0.69 \mathrm{~g} / \mathrm{cm}^{3}\right)$ had greater bulk density than its corresponding paired cacao sites $(\bar{x}=0.61 \mathrm{~g} /$ $\left.\mathrm{cm}^{3}\right)(\mathrm{F}=19.92 ; \mathrm{df}=1,24 ; \mathrm{p}=0.0002$; Fig. 1). Pineapple $\left(\bar{x}=0.79 \mathrm{~g} / \mathrm{cm}^{3}\right)$ also had greater bulk density than corresponding paired cacao sites $\left(\bar{x}=0.66 \mathrm{~g} / \mathrm{cm}^{3}\right)(\mathrm{F}=28.17 ; \mathrm{df}=1,24 ; \mathrm{p} \leq 0.0001 ;$ Fig. 1). The pasture system $\left(\bar{x}=0.60 \mathrm{~g} / \mathrm{cm}^{3}\right)$ did not differ significantly from its paired cacao site $\left(\bar{x}=0.61 \mathrm{~g} / \mathrm{cm}^{3}\right) \quad(\mathrm{F}=1.73 ; \mathrm{df}=1,24$; $\mathrm{p}=0.20$, Fig. 1 ).

Earthworm abundance: Mean number of earthworms did not differ significantly between forest $(\bar{x}=13.9)$ and cacao $(\bar{x}=15.1)(\mathrm{F}=0.16$; $\mathrm{df}=1,16 ; \mathrm{p}=0.69$; Fig. 2). There was also no significant difference in earthworm mass between forest $(\bar{x}=2.93 \mathrm{~g})$ and cacao $(\bar{x}=3.55 \mathrm{~g})$ $(\mathrm{F}=0.76 ; \mathrm{df}=1,16 ; \mathrm{p}=0.3965)$. There were fewer earthworms in the banana plantation $(\bar{x}$ $=1.8$ ) than in its corresponding paired sites of cacao $(\bar{x}=8.6)(\mathrm{F}=38.86 ; \mathrm{df}=1,24 ; \mathrm{p}<0.0001$; Fig. 2). There was also a lower earthworm mass in the banana ( $\bar{x}=0.39 \mathrm{~g})$ than corresponding cacao sites $(\bar{x}=1.73 \mathrm{~g})(\mathrm{F}=7.36 ; \mathrm{df}=1$, $16 ; \mathrm{p}=0.0153)$. In the pineapple plantation, there was a lower number $(\bar{x}=1.5)$ and mass ( $\bar{x}=0.24 \mathrm{~g}$ ) of earthworms than in the corresponding paired sites in the cacao (number: $\bar{x}=8.0$; mass: $\bar{x}=1.86 \mathrm{~g}$ ) (number: $\mathrm{F}=48.03$;

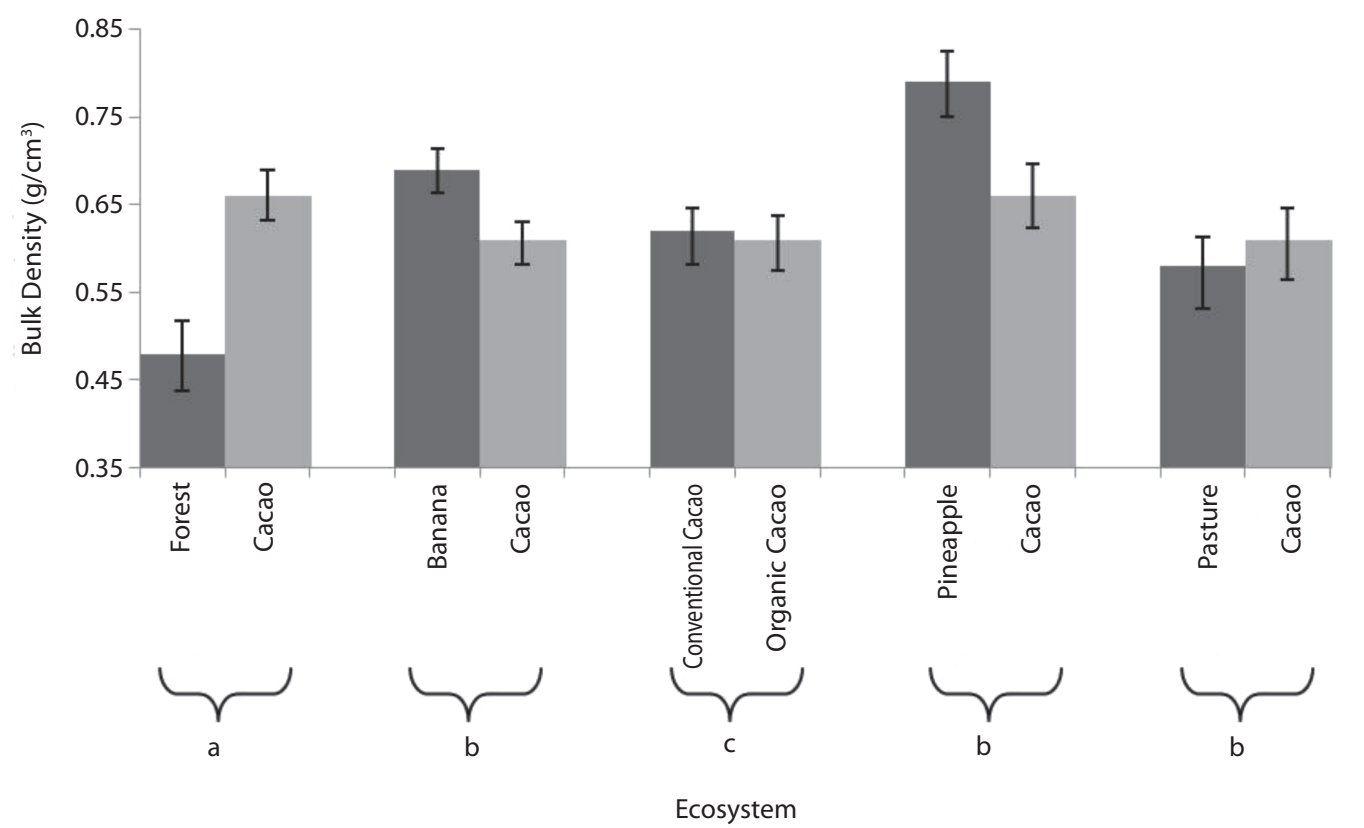

Fig. 1. Mean bulk density by ecosystem. Adjacent bars indicate mean bulk density from paired sampling sites. Error bars represent 95\% LSD confidence interval. a: Bulk density was significantly different between forest and cacao $(\mathrm{p}<0.0001)$. One-way ANOVA, Fisher's LSD. b: Bulk density differed significantly $(\mathrm{p}<0.0001)$. Two-way paired-comparison ANOVA, Fisher's LSD. c: Bulk density was not significantly different ( $\mathrm{p}>0.05)$. Two-way paired-comparison ANOVA, Fisher's LSD. Pueblo Nuevo de Guácimo, Limón Province, Costa Rica. March-April 2012. 


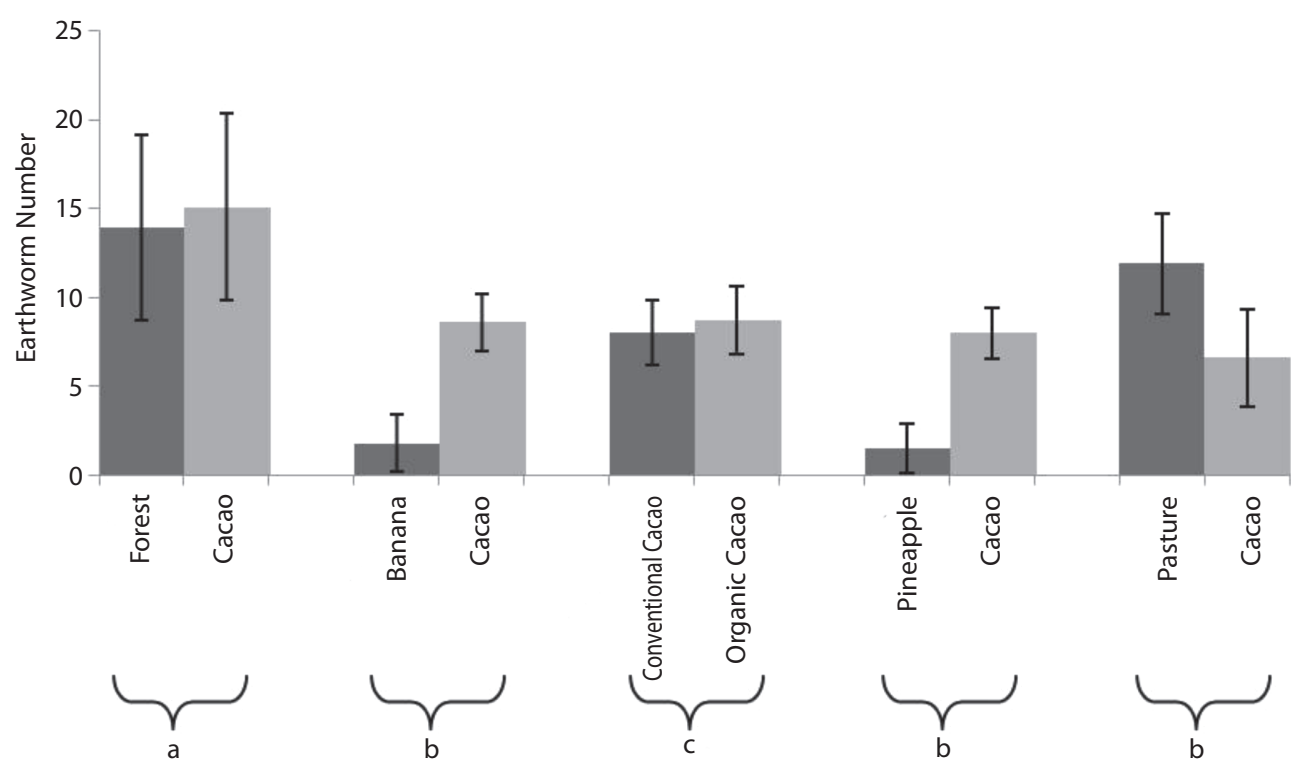

Ecosystem

Fig. 2. Earthworm mean numbers by ecosystem. Adjacent bars indicate mean earthworm number from paired sampling sites. Error bars represent 95\% LSD confidence interval. a: Earthworm number did not differ significantly between forest and cacao ( $>00.05)$. One-way ANOVA. Fisher's LSD. b: Earthworm number differed significantly $(\mathrm{p}<0.01)$. Two-way pairedcomparison ANOVA, Fisher's LSD. c: Earthworm number did not differ significantly ( $p>0.05)$. Two-way paired-comparison ANOVA, Fisher's LSD. Pueblo Nuevo de Guácimo, Limón Province, Costa Rica. March-April 2012.

$\mathrm{df}=1,24 ; \mathrm{p} \leq 0.0001 ;$ mass: $\mathrm{F}=26.19 ; \mathrm{df}=1,20$; $\mathrm{p}=0.0001$ ) (Fig. 2). The pasture ecosystem had a greater number of earthworms $(\bar{x}=11.9)$ than the corresponding cacao paired sites $(\bar{x}=6.6)$ ( $\mathrm{F}=7.91 ; \mathrm{df}=1,24 ; \mathrm{p}=0.0096$; Fig. 2). However, pasture did not have a significantly different earthworm mass $(\bar{x}=2.30 \mathrm{~g})$ than corresponding paired cacao sites $(\bar{x}=1.80 \mathrm{~g})(\mathrm{F}=0.61 ; \mathrm{df}=1$, $16 ; \mathrm{p}=0.45)$.

\section{Physicochemical soil characteristics:} Mean $\mathrm{pH}$ was lower in the forest $(\bar{x}=4.3)$ than the cacao $(\bar{x}=5.8)(\mathrm{p}<0.01$; Table 1). Pineapple $(\bar{x}=4.6)$ also had a lower $\mathrm{pH}$ than its corresponding cacao paired sites $(\bar{x}=5.8)(\mathrm{F}=61.7$; $\mathrm{df}=1,2 ; \mathrm{p}=0.0158$; Table 1$)$. In addition, pasture sites had lower $\mathrm{pH}(\bar{x}=5.2)$ than corresponding cacao paired sites $(\bar{x}=5.6)(\mathrm{F}=24.14$; $\mathrm{df}=1,2 ; \mathrm{p}=0.0390 ;$ Table 1$)$. Banana $\mathrm{pH}(\bar{x}$
$=5.7)$ did not differ significantly from its corresponding paired sites in the cacao $(\bar{x}=6.0)$ (Table 1).

Cation exchange capacity (CEC) was greater in the cacao $\left(\bar{x}=22.55 \mathrm{cmol}^{+} / \mathrm{L}\right)$ than the forest $\left(\bar{x}=10.45 \mathrm{cmol}^{+} / \mathrm{L}\right)(\mathrm{p}<0.05$; Table 1$)$. Cacao CEC was also greater $\left(\bar{x}=22.55 \mathrm{cmol}^{+} / \mathrm{L}\right)$ than in corresponding paired sites of pineapple $\left(\bar{x}=16.74 \mathrm{cmol}^{+} / \mathrm{L}\right)(\mathrm{F}=53.9 ; \mathrm{df}=1,2 ; \mathrm{p}=0.0087$; Table 1). Cacao also had a greater CEC $\left(\bar{x}=21.16 \mathrm{cmol}^{+} / \mathrm{L}\right)$ than corresponding paired sites in pasture $\left(\bar{x}=17.20 \mathrm{cmol}^{+} / \mathrm{L}\right)(\mathrm{F}=113$; $\mathrm{df}=1,2 ; \mathrm{p}=0.0087$; Table 1). However, banana CEC $\left(\bar{x}=15.10 \mathrm{cmol}^{+} / \mathrm{L}\right)$ did not differ significantly from corresponding cacao paired sites $\left(\bar{x}=15.93 \mathrm{cmol}^{+} / \mathrm{L}\right)($ Table 1$)$.

Exchangeable nutrient cations: Forest had less mean concentration of $\mathrm{Ca}^{2+}(\bar{x}$ $\left.=3.90 \mathrm{cmol}^{+} / \mathrm{L}\right)$ than cacao $\left(\bar{x}=17.10 \mathrm{cmol}^{+} / \mathrm{L}\right)$ $\left(\mathrm{p}<0.01\right.$; Table 1). Pineapple also had less $\mathrm{Ca}^{2+}$ 
TABLE 1

Mean soil physicochemical characteristics and exchangeable nutrient cations compared between different agroecosystems

\begin{tabular}{lcccccc} 
Agroecosystems compared & & $\mathrm{pH}$ & $\mathrm{CEC}\left(\mathrm{cmol}^{+} / \mathrm{L}\right)$ & $\mathrm{Ca}^{2+}(\mathrm{mol} / \mathrm{L})$ & $\mathrm{Mg}^{2+}(\mathrm{mol} / \mathrm{L})$ & $\mathrm{K}^{+}(\mathrm{mol} / \mathrm{L})$ \\
Forest vs. Cacao $^{\mathrm{a}}$ & Forest & $4.3^{* *}$ & $10.45^{*}$ & $3.90^{* *}$ & $2.19^{*}$ & $0.16^{*}$ \\
& Cacao & 5.8 & 22.55 & 17.10 & 4.81 & 0.52 \\
Banana vs. Cacao $^{\mathrm{b}}$ & Banana & 5.7 & 15.1 & 10.33 & 3.77 & 0.78 \\
& Cacao & 6.0 & 15.9 & 11.85 & 3.39 & 0.52 \\
Pineapple vs. Cacao & Pineapple & $4.6^{*}$ & $16.74 *$ & $9.80^{*}$ & 4.81 & 0.50 \\
& Cacao & 5.8 & 22.55 & 17.10 & 4.81 & 0.52 \\
Pasture vs. Cacao $^{\mathrm{b}}$ & Pasture & $5.2^{*}$ & $17.20^{* *}$ & $11.72^{* *}$ & 4.69 & 0.28 \\
& Cacao & 5.6 & 21.16 & 16.13 & 4.39 & 0.50 \\
\hline
\end{tabular}

${ }^{\text {a }}$ One-way ANOVAs among all ecosystems Tukey HSD.

b Two-way paired-comparison ANOVA, Fisher LSD.

* means comparison significant at $\leq 0.05 ; * *$ at $\leq 0.01$.

Data obtained from three composite samples taken from paired sampling sites in Pueblo Nuevo de Guácimo, Limón Province, Costa Rica. March-April 2012.

TABLE 2

Mean soil total nutrient and organic carbon levels in different agroecosystems

\begin{tabular}{|c|c|c|c|c|}
\hline Ecosystems compared & & $\mathrm{P}(\mathrm{mg} / \mathrm{L})$ & $\% \mathrm{~N}$ & $\% \mathrm{C}^{\mathrm{c}}$ \\
\hline \multirow[t]{2}{*}{ Forest vs. Cacao ${ }^{\mathrm{a}}$} & Forest & $25.6^{*}$ & $0.49 *$ & $5.59^{*}$ \\
\hline & Cacao & 12.3 & 0.37 & 3.85 \\
\hline \multirow[t]{2}{*}{ Banana vs. Cacao ${ }^{\mathrm{b}}$} & Banana & $72.6^{*}$ & 0.41 & 4.06 \\
\hline & Cacao & 18.0 & 0.47 & 4.39 \\
\hline \multirow[t]{2}{*}{ Pineapple vs. Cacao ${ }^{b}$} & Pineapple & 21.6 & $0.15^{*}$ & $1.34 * *$ \\
\hline & Cacao & 12.3 & 0.37 & 3.85 \\
\hline \multirow[t]{2}{*}{ Pasture vs. Cacao ${ }^{\mathrm{b}}$} & Pasture & 35.6 & 0.46 & 4.28 \\
\hline & Cacao & 15.0 & 0.41 & 4.05 \\
\hline
\end{tabular}

${ }^{a}$ One-way ANOVA among all ecosystems Tukey HSD.

${ }^{\mathrm{b}}$ Two-way paired-comparison ANOVA, Fisher LSD.

c\% $\%$ is directly correlated with \% organic matter $(\mathrm{OM})$ in the soil. To determine estimated $\mathrm{OM}$, multiply values by 1.43 .

*means comparison significant at $\leq 0.05 ; * *$ at $\leq 0.01$.

Data obtained from three composite samples taken from paired sampling sites in Pueblo Nuevo de Guácimo, Limón Province, Costa Rica. March-April 2012.

$\left(\bar{x}=9.80 \mathrm{cmol}^{+} / \mathrm{L}\right)$ than corresponding paired sites in the cacao $\left(\bar{x}=17.10 \mathrm{cmol}^{+} / \mathrm{L}\right)(\mathrm{F}=53.6$; $\mathrm{df}=1,2 ; \mathrm{p}=0.0182$; Table 1). Similarly, $\mathrm{Ca}^{2+}$ was lower in pasture $\left(\bar{x}=11.72 \mathrm{cmol}^{+} / \mathrm{L}\right)$ than cacao $\left(\bar{x}=16.13 \mathrm{cmol}^{+} / \mathrm{L}\right) \quad(\mathrm{F}=121 ; \mathrm{df}=1,2$; $\mathrm{p}=0.0081$; Table 1). Banana, however, did not have a significantly different level of $\mathrm{Ca}^{2+}($ $\bar{x}=10.33 \mathrm{cmol}^{+} / \mathrm{L}$ ) than corresponding cacao paired sites $\left(\bar{x}=11.85 \mathrm{cmol}^{+} / \mathrm{L}\right)$ (Table 1).

Forest $\left(\bar{x}=2.19 \mathrm{cmol}^{+} / \mathrm{L}\right)$ had less $\mathrm{Mg}^{2+}$ than cacao $\left(\bar{x}=4.81 \mathrm{cmol}^{+} / \mathrm{L}\right) \quad(\mathrm{p}<0.05$; Table 1). Mean concentrations of $\mathrm{Mg}^{2+}$ in the other ecosystems varied from $3.39 \mathrm{cmol}^{+} / \mathrm{L}$ to $4.81 \mathrm{cmol}^{+} / \mathrm{L}$, and none differed significantly from corresponding paired sites in the cacao (Table 1).

Reflecting the trends in $\mathrm{Mg}^{2+}$, the only significant difference in $\mathrm{K}^{+}$concentration was between forest $\left(\bar{x}=0.16 \mathrm{cmol}^{+} / \mathrm{L}\right)$ and cacao $\left(\bar{x}=0.52 \mathrm{cmol}^{+} / \mathrm{L}\right) \quad(\mathrm{p}<0.05$; Table 1). While no other ecosystems differed significantly from corresponding cacao paired sites, $\mathrm{K}^{+}$ concentration in banana $\left(\bar{x}=0.78 \mathrm{cmol}^{+} / \mathrm{L}\right)$ tended to be greater than that in cacao $(\bar{x}$ 
$\left.=0.52 \mathrm{cmol}^{+} / \mathrm{L}\right)$. The $\mathrm{K}^{+}$concentration in pasture $\left(\bar{x}=0.28 \mathrm{cmol}^{+} / 1\right)$ tended to be less than that in cacao $\left(\bar{x}=0.50 \mathrm{cmol}^{+} / \mathrm{L}\right)$ (Table 1$)$.

Total nutrients: Mean phosphorus levels were significantly greater in forest $(\bar{x}$ $=25.6 \mathrm{mg} / \mathrm{L})$ than cacao $(\bar{x}=12.3 \mathrm{mg} / \mathrm{L})$ (Table $2)$. In the other ecosystems, there was great variation in $\mathrm{P}$ levels among sampling stations, even within the same ecosystem. Although there were no significant differences between ecosystems, the organic cacao consistently had a lower mean P level than its corresponding paired sites in banana, pineapple, and pastureland (Table 2).

Mean percentage of $\mathrm{N}$ did not differ significantly between forest $(\bar{x}=0.49 \%)$ and cacao ( $\bar{x}=0.37 \%)(\mathrm{p}>0.05$; Table 2$)$. Other ecosystems showed very similar mean $\% \mathrm{~N}$ values which did not differ significantly from corresponding paired sites in the cacao; values ranged from $0.37 \%$ to $0.47 \%$ with the exception of pineapple, which had a much lower $\% \mathrm{~N}(\bar{x}=0.15 \%)$ than its paired cacao sites $(\bar{x}=0.37)(\mathrm{F}=43.6$; $\mathrm{df}=1,2 ; \mathrm{p}=0.0222$; Table 2).

Soil organic carbon: Mean percentage of organic carbon $(\% \mathrm{C})$ did not differ significantly between the forest ecosystem $(\bar{x}=5.59 \%)$ and cacao $(\bar{x}=3.85) \quad(\mathrm{p}>0.05$; Table 2$)$. However, mean percentage of $\mathrm{C}$ was lower in the pineapple $(\bar{x}=1.34 \%)$ than corresponding paired sites in the cacao $(\bar{x}=3.85 \%)(\mathrm{F}=82.6 ; \mathrm{df}=1,2$; $\mathrm{p}=0.0119$; Table 2). Percentage of $\mathrm{C}$ in banana and pasture did not differ significantly from that of corresponding paired sites in organic cacao, ranging from $3.88 \%$ to $4.39 \%$ (Table 2 ).

All results of the above comparisons (Tables 1, 2) for "conventional cacao" plots did not differ significantly from those of their paired sites in the organic cacao.

\section{DISCUSSION}

Soil bulk density is an indication of soil physical structure. A lower bulk density facilitates unrestricted root growth, oxygen and water flow through the soil (USDA, 1999).
The lower bulk density in the forest and cacao indicated that the soil structure in these systems was more favorable for plant growth than that of the banana and pineapple monocultures. This could be associated with the greater abundance of earthworms and more complex root structure in these agriculture systems. Abundant trees in these systems also add organic material to the soil through litterfall which may contribute to lesser soil compaction. Ten years of organic compost addition to the cacao soil probably was the greatest factor in improving its soil bulk density. In contrast, all natural vegetation is removed from the banana and pineapple plantations for "monocrop" cultivation, leaving the soil exposed to the elements. Intensive cropping, trampling of soil by workers, lack of organic material addition, and pounding of rain can compact the soil, leading to an undesirably high bulk density (Hajabbasi, Jalalian, \& Karimzadeh, 1997).

The soil in the cacao had a greater bulk density than that in the forest, suggesting that while preferable to banana and pineapple monoculture, agroforestry management did not attain a soil structure as favorable as the natural forest. A study of livestock pasture found a similar relationship between cacao and forest bulk density, showing that an agroforestry system had intermediate levels of soil compaction and bulk density between a conventional monocropped pasture and natural forest (Vallejo et al., 2010). While I didn't find significant differences between cacao and pasture, the cacao plantation was previously managed as pasture before its conversion 30 years ago; previous research has found that, over time, soil under agroforestry management can continue to decrease in bulk density (Isaac et al., 2005).

Earthworm abundance was greater in the cacao than in the monoculture banana and pineapple systems, and was similar between the cacao and forest. This suggests that agroforestry management of cacao better mimics the macroinvertebrate population of a natural rainforest. This could be related to the presence of shade trees in the cacao and forest, which create a favorable environment for earthworms. 
A study of earthworms in coffee plantations in Turrialba, Costa Rica found that earthworm density and fresh weight were greater in plantations under shade vs sun, and organic vs. conventional management (Sánchez-de Leon et al., 2006).

Earthworms usually have positive effects on soil quality: as they feed and burrow through the soil, they aid in decomposition of organic matter, nutrient cycling, microbial activity, soil porosity and bulk density (Fragoso et al., 1997; Brown et al., 1999). However, they can also negatively affect agricultural production by competing with plants for water and nutrients (Brown et al., 1999). The specific benefits or drawbacks to earthworm presence depend on the type of agricultural system and the species of earthworms present (Fragoso et al., 1997, Brown et al., 1999). Exotic earthworms can replace native species, reducing the productivity of the ecosystem (Fragoso et al., 1997). Exotics can tolerate a wider range of soil conditions, while native earthworms usually can't survive in disturbed ecosystems like banana or pineapple monocultures (Lee, 1983). Case studies have shown that in tropical ecosystems native earthworm species are more likely to be maintained when there are many trees, chemicals are not used, and organic inputs are dominant in the system (Fragoso et al., 1997). It was not within the scope of this study to classify the earthworms found in the different agricultural systems into species or functional groups, but future studies might find that the species composition of earthworms differs depending on the agricultural system.

Regarding physicochemical soil characteristics, the more neutral $\mathrm{pH}$ that I found in cacao as compared to the banana and pineapple monocultures is consistent with previous research showing greater $\mathrm{pH}$ in agroforestry than monocultures (Sharma et al., 2009). In tropical forest and agroforestry systems, the deposition of bases over many years of tree growth can increase the $\mathrm{pH}$ of the soil, buffering the effects of nutrient leaching (Young, 1989; Nair, Buresh, Mugendi, \& Latt, 1999; Sharma et al., 2009). The $\mathrm{pH}$ in the native forest was the lowest of all ecosystems studied. Forests in the humid tropics of Latin America have a greater percentage of acid soils (82\%) compared to those in Africa (56\%) or Asia (38\%) (Sánchez, 1987).

Cation exchange capacity (CEC) indicates the nutrient retention capability of a soil by measuring the quantity of available negative charges to which nutrient cations such as $\mathrm{K}^{+}$, $\mathrm{Ca}^{2+}$, and $\mathrm{Mg}^{2+}$ can bind. A greater CEC provides a potential bank of nutrients to replace those taken up by plants or leached by rainwater (Camberato, 2001). Soil with greater quantities of clay and organic matter tends to have greater CEC (Camberato, 2001). In my study, CEC was lowest in the native forest, even though it had a greater amount of organic carbon. This is probably associated with the low $\mathrm{pH}$ in the forest; more acidic soils have fewer negative charges, and many of the binding sites are occupied by $\mathrm{H}^{+}$and $\mathrm{Al}^{3+}$ cations $\left(\mathrm{Al}^{3+}\right.$ is present in cation form at $\mathrm{pH}$ lower than 5.0) (Lines-Kelly 1993). This trend of increasing CEC with greater $\mathrm{pH}$ carried overall among all ecosystems. Of the agricultural systems, CEC was lowest in the banana and pineapple monocultures, intermediate in the pasture, and greatest in the cacao. This is consistent with the results of a past study which found significantly greater CEC under an agroforestry system than pastoral land, and consequently greater CEC under pastoral than arable land (Sharma et al., 2009).

Regarding exchangeable nutrient cations, such cations as $\mathrm{Ca}^{2+}, \mathrm{Mg}^{2+}$, and $\mathrm{K}^{+}$occupy the negative binding sites in the soil indicated by CEC. As with CEC, native forest had the lowest levels of $\mathrm{Ca}^{2+}, \mathrm{Mg}^{2+}$, and $\mathrm{K}^{+}$of all ecosystems. This contradicts past research which suggests that decomposition of litterfall and neutral soil reactions lead to greater nutrient cation concentrations in tree-based systems (Lal, 1989; Sharma et al., 2009). Greater nutrient cation concentrations in the agricultural systems may be attributed to the application of fertilizer, whether organic (such as the compost used in the cacao) or chemical (for example, it appeared that calcium carbonate had recently 
been applied to the banana plantation when soil samples were taken). The cacao had significantly more $\mathrm{Ca}^{2+}$ than pasture or pineapple sites, and while I did not find a significant difference between banana and cacao, this may have been related to the recent application of calcium carbonate in the banana. Differences among agricultural systems in $\mathrm{Mg}^{+}$and $\mathrm{K}^{+}$ were not as great, although previous research has found that agroforestry systems have greater amounts of these nutrients than pastoral or arable land (Sharma et al., 2009).

Regarding total nutrients, cacao tended to have lower levels of phosphorus (P) than its corresponding paired sites in the banana and pineapple although these differences were not significant. $\mathrm{P}$ was also significantly greater in the forest than the cacao. Nitrogen $(\mathrm{N})$ percentage did not differ as greatly among ecosystems as $\mathrm{P}$, but was significantly lower in the pineapple than the cacao. These results contradict previous studies which have shown that levels of $\mathrm{N}, \mathrm{P}$, and potassium were all greater under tree cover than in open field monocultures (Aggarwal, 1980; Radwanski \& Wickens, 1981; Young, 1989). The greater levels of $\mathrm{P}$ in banana and pineapple may be explained by chemical fertilizer application which artificially increases nutrient levels. Future studies analyzing nutrient content of rainwater runoff would help determine if nutrients such as $\mathrm{N}$ and $\mathrm{P}$ are being applied in excess, an economically ineffective and environmentally damaging practice.

Cacao also had slightly lower $\mathrm{P}$ and $\% \mathrm{~N}$ than pasture. Sharma et al. (2009) attributed higher levels of $\mathrm{N}$ and $\mathrm{P}$ in pastoral land than an agroforestry system to nutrients added by manure from grazing cattle.

Regarding soil organic carbon, the percentage of organic carbon in the soil is directly related to the soil organic matter (SOM), and can therefore be used to model SOM levels. While not significantly different, the forest did have greater $\% \mathrm{C}$ than the cacao and the greatest $\% \mathrm{C}$ overall. Although the only ecosystem with a significantly lower $\% \mathrm{C}$ than organic cacao was pineapple; banana had slightly lower
$\% \mathrm{C}$ as well. Previous research has also found greater SOM in native forest and agroforestry systems than monocropping, which has been attributed to greater root biomass and litterfall (Szott, Fernandes, \& Sánchez, 1991; Madhumitha, Singh, \& Khan, 1997; Sharma et al., 2009). The pasture had a slightly greater $\% \mathrm{C}$ than its paired sites in the cacao, but not significantly so. Past studies comparing pasture and agroforestry systems have had conflicting results: some found that pasture has the capacity to sequester more carbon, while others found more carbon in agroforestry systems (Lantz, Lal, \& Kimble, 2001; Sharma et al., 2009).

This study indicates that organic agroforestry management of cacao results in soil with greater overall quality for plant and animal health than banana and pineapple monocultures. Shade trees add organic material through litterfall and provide a haven for wild animals, which in turn add their own nutrients and organic matter to the soil. The lack of chemical additives allows native macroinvertebrates such as earthworms to flourish, which also improves bulk density and nutrient content. When agriculture is managed to mimic a native rainforest ecosystem, the results of this study showed that many factors work together in a complicated net of interactions to maintain soil fertility.

Banana and pineapple monocultures, in contrast, maintain high levels of productivity only with the addition of chemical fertilizers and pesticides. As this study shows, soil quality is reduced; it is unlikely that this soil will support such aggressive management for many years without a drastic decline in productivity.

Because many residents of Limón Province rely on agriculture as their livelihood, it is essential to maintain the fertility of the soil so that it can support the healthy crop growth in future generations. Banana and pineapple growers may try to mimic the agroforestry approach of cacao production, imitating as closely as possible the native ecosystem. This might involve allowing ground cover to prevent soil compaction; finding organic alternatives to fertilizers and pesticides; or even developing a 
more integrated agroforestry approach like that of the cacao plantation. There are examples of the successful cultivation of banana and pineapple alongside other crop plants (such as cacao) in agroforestry systems (Khaleque \& Gold, 1993; Jose, 2009). Agroforestry management of not just cacao but banana and pineapple as well may indeed be the best way to maintain soil quality in the region.

\section{ACKNOWLEDGMENTS}

Thanks to Michael McCoy and Christopher Vaughan for logistical assistance, support with fieldwork, and help with manuscript revisions. Thanks also to Hugo Hermelink for providing the use of his cacao plantation, as well as supplies and funding for soil analysis. Geovanny Herrera, Oldemar Miranda, Marco Antonio Herrera, Manuel Herrera and several other employees of Finmac cacao plantation provided assistance with field work, supplies, and background information. The Associated Colleges of the Midwest Costa Rica provided financial support for soil analysis.

\section{RESUMEN}

Efectos de sistemas agrícolas diferentes sobre calidad de suelos en el norte de la provincia de Limón, Costa Rica. Muchos de los ecosistemas boscosos naturales de la provincia de Limón, Costa Rica, se han convertido en monocultivos de banano y piña, lo que ha reducido la biodiversidad y la calidad de los suelos. El manejo agroforestal del cacao (Theobroma cacao) es un sistema alternativo, que puede generar ingresos para los agricultores de la región mientras imita mejor los ecosistemas nativos. En esta investigación se compararon los indicadores físicos, biológicos, y químicos de la calidad del suelo en un cacaotal orgánico y agroforestal, una plantación bananera, una piñera, un potrero y un bosque natural. En general, el suelo del cacaotal tuvo características físicas, biológicas y químicas mejores que los monocultivos de banano y piña, mientras las tendencias en comparación con el potrero fueron menos marcadas. Aunque algunas características del suelo en el cacaotal orgánico, como densidad y cantidad de carbono, fueron inferiores al bosque nativo, la calidad del suelo en el cacaotal imitó mejor la del bosque nativo. Los resultados de esta investigación apoyan el cultivo de cacao como una alternativa deseable al monocultivo de banano y piña.
Palabras clave: banano (Musa acuminata), cacao (Theobroma cacao), calidad del suelo, Costa Rica, manejo agroforestal, cultivo orgánico, piña (Ananus comosus), potrero.

\section{REFERENCES}

Aggarwal, R. K. (1980). Physico-chemical status of soils under "khejri" (Prosopis cineraria Linn.). In H. S. Mann \& S. K. Saxena (Eds.), Khejri (Prosopis cineraria) in the Indian Desert-Its Role in Agroforestry (pp. 32-37). Jodhpur, India: Central Arid Zone Research Institute (CAZRI).

Baldwin, K. R. (2006). Soil quality considerations for organic farmers. Center for Environmental Farming Systems. Raleigh, North Carolina, USA: North Carolina Cooperative Extension Service.

Bonanomi, G., D’Ascoli, R., Antignani, V., Capodilupo, M., Cozzolino, L., Marzioli, R., \& Zoina, A. (2011). Assessing soil quality under intensive cultivation and tree orchards in Southern Italy. Applied Soil Ecology, 47, 184-194.

Brown, G. G., Pashanasi, B., Villenave, C., Patron, J. C., Senapati, B. K., Giri, S., \& Boyer, J. (1999). Effects of earthworms on plant production in the tropics. In P. Lavelle, L. Brussaard, \& P. Hendrix (Eds.), Earthworm management in tropical agroecosystems (pp. 87-148). Wallingford, United Kingdom: CABI Publishing.

Camberato, J. J. (2001). Cation exchange capacity: Everything you want to know and much more. South Carolina Turfgrass Foundation News. Columbia, SC, USA: Clemson University. Retrieved from http:// files.clino.webnode. com/200000022-0bdf60cd97/ What\%20is\%20CEC.pdf

Castillo, L. E., Martínez, E., Ruepert, C., Savage, C., Gilek, M., Pinnock, M., \& Solis, E. (2006). Water quality and macroinvertebrate community response following pesticide applications in a banana plantation, Limon, Costa Rica. The Science of the Total Environment, $367,418-432$.

Doran, J. W., Sarrantonio, M., \& Liebig, M. A. (1996). Soil health and sustainability. In L. S. Donald (Ed.), Advances in Agronomy (pp. 1-54). Lincoln, NE, USA: Academic Press.

Fragoso, C., Brown, G. G., Patrón, J. C., Blanchart, E., Lavelle, P., Pashanasi, B., \& Kumar, T. (1997). Agricultural intensification, soil biodiversity and agroecosystem function in the tropics: The role of earthworms. Applied Soil Ecology, 6, 17-35.

Gregory, M. M., Shea, K. L., \& Bakko, E. B. (2005). Comparing agroecosystems: Effects of cropping and tillage patterns on soil, water, energy use and productivity. Renewable Agriculture and Food Systems, 20, 81-90. 
Hajabbasi, M. A., Jalalian, A., \& Karimzadeh, H. R. (1997). Deforesatation effects on soil physical and chemical properties, Lordegan, Iran. Plant Soil, 190, 301-308.

Holdridge, L. (1964). Life Zone Ecology. San José, Costa Rica: Tropical Science Center.

Isaac, M. E., Gordon, A. M., Thevathasan, N., Oppong, S. K., \& Quashie-Sam, J. (2005). Temporal changes in soil carbon and nitrogen in west African multistrata agroforestry systems: A chronosequence of pools and fluxes. Agroforestry Systems, 65, 23-31.

Jose, S. (2009). Agroforestry for ecosystem services and environmental benefits: An overview. Agroforestry Systems, 76, 1-10.

Khaleque, K. \& Gold, M. A. (1993). Pineapple agroforestry: An indigenous system among the Garo community of Bangladesh. Society and Natural Resources, 6, 71-78.

Lal, R. (1989). Potential of agroforestry as a sustainable alternative to shifting cultivation: Concluding remarks. Agroforestry Systems, 8, 239-242.

Lantz, A., Lal, R., \& Kimble, J. (2001). Land use effects on soil carbon pools in two major land resource areas of Ohio, USA. In D. E. Stott, R. H. Mohtar, \& G. C. Steinhardt (Eds.), Sustaining the Global Farm (pp.499-502). West Lafayette. In: Proceedings of the 10th International Soil Conservation Organization, Purdue University and the USADA-ARS National Soil Erosion Research Laboratory, USA.

Lee, K. E. (1983). Earthworms of tropical region. Some aspects of their ecology and relationships with soils. In J. E. Satchell (Ed.), Earthworm Ecology: From Darwin to Vermiculture (pp. 449-466). London, United Kingdom: Chapman \& Hall. Cited in: Fragoso, C., Brown, G. G., Patrón, J. C., Blanchart, E., Lavelle, P., Pashanasi, B., Senapati, B., \& Kumar, T. (1997). Agricultural intensification, soil biodiversity and agroecosystem function in the tropics: The role of earthworms. Applied Soil Ecology, 6, 17-35.

Lines-Kelly, R. (1993). Cation exchange capacity. In Soil Sense Leaflet. Wollongbar, Australia: Wollongbar Agricultural Institute.

Madhumitha, D., Singh, B. P., \& Khan, S. K. (1997). Effect of major land uses on soil characteristics of alfisols in Meghalaya. Journal of the Indian Society of Soil Science, 45, 547-553.

McNeely, J. \& Schroth, G. (2006). Agroforestry and biodiversity conservation: Traditional practices, present dynamics, and lessons for the future. Biodiversity and Conservation, 15, 549-554.

Nair, P. K. R., Buresh, R. J., Mugendi, D. N., \& Latt, C. R. (1999). Nutrient cycling in tropical agroforestry systems: Myths and science. In L. E. Buck, J. P. Lassoie, \& E. C. M. Fernandes (Eds.), Agroforestry in Sustainable Agricultural Systems (pp.1-31). Boca Raton, FL, USA: CRC.
Obando, O. A. (1982). Mapa semi-detallado de suelos [map]. 1:10,000. San Jose, Costa Rica: HDA Agropecuaria Tica S.A.

Radwanski, S. A. \& Wickens, G. E. (1981). Vegetative fallows and potential value of the neem tree (Azadirachta indica) in the tropics. Economic Botany, 35, 398-414.

Sánchez, P. A. (1987). Management of acid soils in the humid tropics of Latin America. In P. A. Sánchez, E. R. Stoner, \& E. Pushparajah (Eds.), Management of Acid Tropical Soils for Sustainable Agriculture. International Board for Soil Research and Management Proceedings No. 2 (pp. 64-107). Bangkok, Thailand: International Board for Soil Research and Management.

Sánchez-de Leon, Y., de Melo, E., Soto, G., Johnson-Maynard, J., \& Lugo-Perez, J. (2006). Earthworm populations, microbial biomass and production in different experimental coffee agroforestry management systems. Caribbean Journal of Science, 42, 397-409.

Sharma, K. L., Raju, K. R., Das, S. K., Rao, B., Kulkarni, B. S., Srinivas, K., \& Gajbhiye, P. N. (2009). Soil fertility and quality assessment under tree-, crop-, and pasturebased land-use systems in a rainfed environment. Communications in Soil Science and Plant Analysis, 40, 1436-1461.

Sokal, R. R. \& Rohlf, F. J. (2012). Biometry: The principles and practice of statistics in biological research. New York, NY, USA: W. H. Freeman \& Co.

Statpoint Technologies, Inc. (2012). Statgraphics Centurion [computer software]. Available from http://www.statgraphics.com.

Szott, L. T., Fernandes, E. C. M., \& Sánchez, P. A. (1991). Soil-plant interactions in agroforestry systems. Forest Ecology Management, 45, 127-152.

Tully, K. L. \& Lawrence, D. (2011). Closing the loop: Nutrient balances in organic and conventional coffee agroforests. Journal of Sustainable Development, 35 , 671-695.

USDA (United States Department of Agriculture). (1999). Soil quality test kit guide. Washington, D.C., USA: United States Department of Agriculture Soil Quality Institute.

Vallejo, V. E., Roldan, F., \& Dick, R. P. (2010). Soil enzymatic activities and microbial biomass in an integrated agroforestry chronosequence compared to monoculture and a native forest of Colombia. Biology and Fertility of Soils, 46, 577-587.

Vaughan, C., Ramírez, O., Herrera, G., \& Guries, R. (2007). Spatial ecology and conservation of two sloth species in a cacao landscape in Limón, Costa Rica. Biodiversity and Conservation, 16, 2293-2310.

Young, A. (1989). Agroforestry for Soil Conservation. Wallingford, UK: CAB International. 
